Article

\title{
Beastly Boasts and Apocalyptic Affects: Reading Revelation in a Time of Trump and a Time of Plague
}

\author{
Stephen D. Moore
}

The Theological School, Drew University, Madison, NJ 07940, USA; smoore@drew.edu

Received: 6 June 2020; Accepted: 7 July 2020; Published: 10 July 2020

check for updates

\begin{abstract}
Waxing "biblical," Donald Trump has described the COVID-19 pandemic as a "plague." In a different but related register, millions of Christians worldwide have interpreted the pandemic as one of the eschatological plagues prophesied in the Book of Revelation. This article appropriates the reading tactics of Gilles Deleuze and Félix Guattari, together with the resources of affect theory, to connect the Book of Revelation with both the Trump phenomenon and the COVID-19 pandemic. Specifically, the article attempts to relate Revelation's Beast to Trump (to unleash the Beast against Trump) non-eschatologically, in a non-representationalist reading strategy, and to analyze how Trump has manipulated the pandemic for his post-ideological ends.
\end{abstract}

Keywords: Book of Revelation; apocalyptic; eschatology; Donald J. Trump; COVID-19; Gilles Deleuze; Félix Guattari; affect theory

"And I saw another sign in heaven, great and marvellous, seven angels having the seven last plagues; for in them is filled up the wrath of God."

-Revelation 15:1, KJV

"To my great trouble, hear that the plague is come into the City."

—Samuel Pepys, London, 1665

"We're gonna beat this plague."

It was not the best of times to begin with. Indeed, this unforeseen time, this time of Trump, seemed already, for many of us, to be the worst of times. That was before COVID-19, this time of plague. Here in the United States, Trump time and plague time have looped around each other in a helical spiral that mimics the structure of the virus itself: "The coronavirus fusion peptide forms a short helix and a loop ..." (Li 2016, p. 237). Curling around both of these times in turn, enfolding them in its sinuous embrace, is the Book of Revelation. What pulls COVID-19, with Trump clinging onto it, into Revelation's eschatological coils? Many factors, as we shall see, but not least the apocalyptically charged term "plague." Trump has described COVID-19 as a "plague" more than once, most (melo)dramatically, and most "biblically," in a tweet of 3 May 2020: "And then came a Plague, a great and powerful Plague, and the World was never to be the same again! But America rose from this death and destruction, always remembering its many lost souls, and the lost souls all over the World, and became greater than ever before!"1 I argue below that the term "plague" perfectly mediates Trump's political post-ideology. But first let me unpack my (un)methodological assumptions and lay them out for inspection.

1 Donald J. Trump, Twitter post, May 3, 2020, 10:43 a.m., http://twitter.com/realDonaldTrump. 


\section{Revelation beyond Representation}

Revelation plucks the localized plagues of Egypt from the Book of Exodus (7:1-15:21) and inflates them horribly, transmuting them into global plagues (e.g., 9:18: "By these three plagues [pleggai] a third of humankind was killed"; 2 see also 9:20;15:1, 6, 8; 16:9, 21). What do Revelation's plagues have to do with COVID-19? Everything or nothing, depending on whom you read. And there is much to read, a sanity-destabilizing quantity of material to read. On this day of 29 May 2020, feeding "COVID-19 Book of Revelation" into the Google search engine causes it to spit out almost forty million results, most of them interpretations of the virus as one or other of Revelation's eschatological plagues. This is what Revelation is for, this is what Revelation does. This is the default function of this disaster-voracious book in a time of global crisis. Specifically, for hundreds of millions of Christians worldwide, Revelation is subsuming the infra-agential activity of submicroscopic suborganisms under the supra-agential activity of a yet more invisible and more inscrutable divine being, thereby transforming a time of pandemic into a time of plague.

My own claim is not that the COVID-19 pandemic is prophesied in the Book of Revelation; my claim is rather that Revelation possesses convenient sockets into which the pandemic and the Trump presidency alike may be plugged so as to illuminate both phenomena. My understanding of how the pandemic and the president are connected to Revelation is informed by the opening salvo of Gilles Deleuze and Félix Guattari's A Thousand Plateaus ([1980] 1987, pp. 3-4), which succinctly elaborates their pragmatic post-hermeneutical text theory. Channeling Deleuze and Guattari and applying their pronouncements to Revelation, let me explain that I will not be inquiring in this article what Revelation might have meant in its original context of production so much as "ask[ing] what it functions with" in current contexts of reception, "in connection with what other things it does or does not transmit intensities," and "in which other multiplicities its own are inserted and metamorphosed" (p. 4). "Intensities" is a synonym for "affects" for Deleuze and Guattari, and affect will loom large in this article. Like any work of literature, Revelation is "a little machine" (p. 4), but it is immensely more powerful than most other literary machines, not least in its affective capacities. To understand what this little machine does, what it is capable of doing, is to determine which other machines it "can be plugged into" so as to operate optimally (p. 4). These other machines have assumed a variety of forms through the centuries: textual and nontextual, discursive and nondiscursive, human and nonhuman, organic and nonorganic. ${ }^{3}$ They have ranged from the Book of Daniel to the Roman imperial cult, from the medieval papacy to the bubonic plague, and from the Trump presidency to the novel coronavirus pandemic, to cull only a small sample of the often enormous machines that have interlocked intricately in the seething "mechanosphere" (Deleuze and Guattari [1980] 1987, pp. 71, 514) in which Revelation has operated.

In adapting Deleuze and Guattari's reading strategies, I step to the side of the standard critical-scholarly approach to Revelation, which is a depth hermeneutic whose two supporting struts are intentionalism and representationalism. Employing the formidable historical-critical tools developed during the Enlightenment and its aftermath, scholars have effortlessly bored down through two millenia of presentist and futurist interpretations of Revelation and carved out a capacious cavern that is at once the interior of John of Patmos's skull, a space in which presumed authorial intentions flit about, begging to be netted and described, and John of Patmos's social world whose inhabitants and institutions are assumed to be represented in his symbolic visions, which as such demand decoding. I hasten to add that this depth hermeneutic has been immensely productive and indispensably valuable.

2 While I occasionally have recourse in this article to the archaic power of the King James Version, my go-to English translation of Revelation is the New Revised Standard Version, whether to quote it directly or modify its rendition of the Greek.

3 "Machine" is a Deleuzoguattarian metaconcept, a fluid, multifaceted figure for the infinite interconnectivity and incessant productivity of all life. For example, "[t]he [human] breast is a machine that produces milk, and the mouth a machine coupled to it" (Deleuze and Guattari 1977, p. 1); but the orchid and the male wasp also have a machinic relationship, the former "ow[ing] its reproduction to a part of another machine" (p. 285). 
But the mine has long been exhausted, commentaries on Revelation saying less and less that is original at ever greater length as the decades roll by. Contextual hermeneuts of various stripes-notably, feminists, womanists, (other) liberationists, queer, postcolonial, and decolonial critics, along with ecocritics-do read Revelation in ways that effectively plug its (re)constructed context of production into their lived contexts of reception. ${ }^{4}$ Such readings regularly critique certain of what they take to be Revelation's representations, such as its representation of imperial Rome as a promiscuous woman in need of sexual shaming and violent eradicating (Rev 14:8; 17:1-18; 18:3, 9; 19:2).

What if representation itself, rather than specific representations, were the object of critique? What readings, what retoolings, of Revelation might that make possible? As I attempt to show in what follows, it might enable us, while still working out of a critical paradigm, to relate Revelation's visions to consequential contemporary phenomena like the Trump presidency or the COVID-19 pandemic, not by reading for relations of resemblance or analogy between these visions and events (Trump, say, craving adulation above all, resembling the Beast of Revelation that demands the worship of all-13:4, $8,12,15)$ but rather by reading the events as though they were intricately folded into the visions, coextensive with and co-implicated in them (Trump and the Beast commingling, each passing into and flowing through the other) in a continuous plane of interconnection (cf. Deleuze and Guattari [1980] 1987, p. 255).

How might this reading strategy be related to pop-evangelical, apocalyptic expositions of "Bible prophecy," that derided other of critical biblical scholarship? Trump has provided a blimp-sized target for such expositions, some of them tongue in cheek (for a prime tabloid example, see Evans 2017), ${ }^{5}$ many more of them deadly serious (for book-length examples, see Moelhauser 2016; Varos 2017; Dane 2018). In almost all of them, Trump is identified as the Beast, Revelation's ultimate image for the absolute despot (13:1-18). More precisely, the Beast represents the president in such expositions, the Beast having always, with inhuman patience, been waiting in the wings of history, so to speak, to represent this particular president-all of which is to say that the "prophecy news watch" approach to Revelation is an allegorical enterprise (cf. Deleuze [1978] 1997, p. 49), each use-worn vision in the ancient book finally finding its corresponding person or event in the contemporary milieu.

How might we relate the Beast to Trump-unleash the Beast against Trump-non-allegorically, in a non-representationalist reading strategy, impelled by the non-representationalist turn in critical theory and its "constant war on frozen states" (Thrift 2008, p. 5)? ${ }^{6}$ In the case of Revelation, the frozen state would be a fossilized Beast, a Beast excavated by historical critics of Revelation, most of whom never tire of telling each other and anyone else who will listen that the Beast was-and, indeed, still is-the emperor Nero, ${ }^{7}$ and as such a metonym for imperial Rome. Non-representational theory would reanimate this mummified Beast, would cause all fourteen of its eyes (cf. Rev 13:1;17:3, 7,9) to snap open abruptly and alarmingly.

4 See, e.g., the essays gathered in Rhoads (2005), together with Pippin (1992); Keller (1996); Blount (2005); Schússler Fiorenza (2007); Sánchez (2008); Levine and Robbins (2009); Smith (2014); Kiel (2017); and Menéndez-Antuña (2018).

5 "One of Trump's buildings is at 666 Fifth Avenue-which he bought for $\$ 1.8$ billion. And $18=3 \times 6$, so: 666 . The Trump family is also in the process of building a $\$ 666$ million tower at One Journal Square-with a reported height of $666 \mathrm{ft}$. They even claim that Trump Tower is satanic-as, again, it is reportedly $666 \mathrm{ft}$. high. Trump himself lives in 'gold-plated opulence' on the 66th floor. It doesn't stop there-because 2016 [the year Trump was elected] $\ldots=666+666+666+6+6+6$. Scared yet?" (Evans 2017, riffing on Rev 13:18).

6 Twenty-first-century theory has thus far been characterized by three complexly interrelated "turns": an affective turn (Clough and Halley 2007; Gregg and Seigworth 2010), a nonhuman turn (Grusin 2015; Roffe and Stark 2015), and a non-representationalist turn (Thrift 2008; Anderson and Harrison 2010; Boyd and Edwardes 2019). The philosophy of Deleuze together with the collaborative thought-experiments of Deleuze and Guattari have been major catalysts-although by no means the only catalysts-for all three turns. Introducing the collection Non-Representational Methodologies, Phillip Vannini (2015, p. 2) claims: “Non-representational theory is now widely considered to be the successor of postmodern theory, the logical development of poststructuralist thought, and the most notable intellectual force behind the turn away from cognition, symbolic meaning, and textuality."

7 A conclusion reached by applying the principles of ancient gematria/isopsephy to Rev 13:18 ("Let anyone with understanding calculate the number of the Beast, for it is the number of a person. Its number is six hundred sixty-six"), using Hebrew as the code language. 
Reconceived non-representationally, Revelation's Beast would not, of course, simply reawaken, return to life, as a representation of Donald J. Trump, squeezing into Trump's navy-blue shoulder-padded jacket, clipping on his too-long Republican-red tie, curiously running its newly acquired fingers through his wispy orange hair (combover? toupee?). One might, indeed, be tempted to imagine the opposite- that Trump is instead a representation of the Beast, in the sense that this particular U.S. president is but the latest in a long line of autocrats or would-be autocrats who have re-presented the Beast, made it present once again, by stepping into the role scripted for it in Revelation, thereby embodying and enacting it anew. But because Revelation's Beast thus reanimated, plugged into Donald J. Trump, is now more and other than it was before, is irreducibly different from all previous actualizations of the Beast, it cannot simply be regarded as an original that preexisted the Trumpian Beast in a primal Platonic sense, an original of which the president would merely be the latest copy; and so the concept of representation is of little use in describing the operative mechanism, the engine, of the Trump-Beast assemblage.

In his own essay on Revelation ([1978] 1997), Deleuze characterizes the representationalist decoding of its symbols as an arid exercise in "allegorical" interpretation. Although Revelation appears to invite allegorical exposition, even or especially from critical scholars of the book (chimerical character $\chi$ represents ancient historical person $A$; bizarre detail $\rho$ represents abstract quality $B$; surreal visionary sequence $\sigma$ represents ancient social institution $C$, and so on), it simultaneously opens itself up to an altogether different mode of actualization, one that is attuned not to remote events, ideas, or other abstractions but to present, action-impelling emotions, affects, and sensations-an actualization that does not attempt to reify and thereby neutralize Revelation's symbols by uttering determinative, delimiting pronouncements on their meaning but seeks to flow with them instead, to be carried along in their current, to see where else we might be borne by means of them, in which as yet unthought territories we might land, and in which other arrangements of power we might thereby be equipped to intervene. ${ }^{8}$

In order, however, to relate Revelation to the Trump phenomenon, including his political manipulation of the COVID-19 crisis, we must first put the question to Trump that we earlier put to Revelation. That question (also a Deleuzoguattarian one) is not a question of identity but of function, not of hermeneutics but of pragmatics, not who is Donald Trump? but what is Donald Trump? What manner of machine is "the Donald"? And what does this Donald do? "Pragmatics is a politics of language" (Deleuze and Guattari [1980] 1987, p. 82), and never more than when the subject of analysis is a politician.

The "what is Trump?" question has already been pondered by Brian Massumi, principal architect of affect theory in the Deleuzian mode. ${ }^{9}$ Acute attunement to the movements of affect is essential to the task of analyzing political power after ideology (Massumi 2002, p. 42; 2015, pp. 32-33; see further Grossberg 2018, pp. 10-11, 91-111), and Trump epitomizes post-ideological politics, as we shall see. In what follows, I aim to create a bricolage (cf. Deleuze and Guattari 1977, p. 7) that begins with Massumi's affective analysis of the Trump phenomenon; extends to further pertinent reflection by other affect theorists, much of it also on Trump; ${ }^{10}$ and gradually braids in the COVID-19 pandemic, all the while interfacing also with the Book of Revelation in aleatory fashion as points of connection present themselves (as they inevitably do, for this is precisely the kind of literary machine that Revelation is and always has been).

8 This is a highly paraphrastic rendering of certain exceedingly dense but fascinatingly suggestive pages of Deleuze's "Nietzsche and Saint Paul, Lawrence and John of Patmos" (1997); see pp. 46-52 passim.

9 Donovan Schaefer (2015, pp. 23-34) distinguishes the Deleuzian current in affect theory from a phenomenological current. Bray and Moore (2020, pp. 1-6) attempt to add further nuance to Schaefer's map. Biblical-scholarly experiments with affect theory have included Koosed and Moore (2014); Kotrosits (2015, 2016); Moore (2017, pp. 15-59); Black and Koosed (2019).

10 For Trump has, indeed, attracted much attention from theorists and scholars of affect; see, e.g., Berlant (2016, 2017b); Anderson (2017); Massumi (2017, 2018, pp. 65, 77-78, 83-86); Connolly (2017); Morgan (2017); Richardson (2017); Bray (2018); Grossberg (2018); Ott and Dickinson (2019); Schaefer (2019). 


\section{Boasts, Blasphemies, and Tweets from the Bottomless Abyss}

I propose to address four questions as though they were one question: What is Revelation's Beast? What does the Beast do? What is Donald Trump? What does Trump do? The Beast embodies empire, as it always has, the empire the Beast embodies always reconfiguring, always mutating. The Beast possesses, perennially, "power," a "throne," and "great authority" (Rev 13:2). Or, in the incumbent Beast's own words: "Well, I have the ultimate authority. The president of the United States has the authority to do [fumbling pause] what the president has the authority to do, which is very powerful ... . If somebody's the president of the United States the authority is total, and that's the way it's gotta be ... . Total. It's total."11

The empire that the current Beast embodies, the ultimate source of its absolute power, exceeds the nation for which the Beast is so solicitous ("We gotta put America first!"), overflows its borders incessantly. That empire is global capitalism. But "embodies" is not the best term here: it is too static a descriptor for what the Beast is, for what it does, in relation to the chaotic, hydraulic megamachine that is global capitalism, an inconceivably colossal, infinitely fluid, incessantly restless "monetary mass" that circulates everywhere and encircles everything (cf. Deleuze and Guattari [1980] 1987, p. 453). The Beast does not interpose its own considerable bulk between the voracious megamachine and its most vulnerable victims. The Beast loves walls, loves barriers, but is not itself a rampart of this sort. The Beast is "not a bulwark against the excesses of capitalism" but rather "an opening of the floodgates" (Massumi 2017). The Beast is itself, indeed, both the open floodgate and what flows through the floodgate. Far from taking a stand against capitalism's excesses, the Beast "flows with them" (Massumi 2017) and becomes them, identifying itself utterly with unfettered immoderation.

The Beast ascended to its throne precisely because of its "supposed capitalist prowess" (Massumi 2017). And what is the now enthroned Beast but the very "personification of capital" (Massumi 2017)? "A personification is an expression of nonhuman forces" (Massumi 2018, p. 77), and never more than in this instance. The Beast has ascended "from the bottomless abyss" (Rev 11:7), ${ }^{12}$ but the Beast is also itself that abyss. Like capitalism itself, the Beast has, with spectacular success, "[made] a habit of feeding on the contradictions [it] give[s] rise to, on the crises [it] provoke[s], on the anxieties [it] engender[s]" (Deleuze and Guattari 1977, p. 152). Like capitalism too, the Beast has long "ceased doubting itself," knowing that "no one has ever died from contradictions," not even billionaire populist politicians. "And the more it breaks down, ... the better it works" (p. 152). If capitalism is indeed "the end of history" (p. 154), then the Beast is the (im)perfect personification of that-of this-particular eschatological moment.

It is not only from the abyss that the Beast has ascended. Revelation 13:1 reads: "And I saw a Beast rising out of the sea." What is this sea that it should birth such a Beast? This Beast is equipped with "a mouth," we also read, and that mouth laloun megala, "is speaking boastful things" (13:5; cf. Dan $7: 8,11,20$ ). More literally, and more aptly for the current Beast, that mouth is "talking big." "I play to people's fantasies," the Beast long ago confessed. "People may not always think big themselves, but they can still get very excited by those who do. That's why a little hyperbole never hurts. People want to believe that something is the biggest and the greatest and the most spectacular" (Trump and Schwartz 1987, p. 58).

The Beast's incessant bragging is awash in inconsistency, as we already noted. Its mouth utters "one thing one day, something else the next. The center does not hold. There is no center. There is just an eddy of bluster on the roiling seas of social media" (Massumi 2017). This then is the sea, these then are the seas, out of which the Beast has emerged. The particular sectors of social media

11 “Donald Trump: 'When somebody is president of the United States, the authority is total'—Video," The Guardian, April 14, 2020, https://www.theguardian.com/us-news/video/2020/apr/14/donald-trump-when-somebody-is-president-of-the-unitedstates-the-authority-is-total-video.

12 The idea of infinite depth is implied in the Greek term abyssos (Aune 1998, pp. 525-26; Koester 2014, pp. 456-57), which is used seven times in Revelation, twice with reference to the Beast (11:7; 17:8). NRSV renders abyssos as "bottomless pit." 
that are the Beast's habitat "[breed] dark, degrading, and dehumanizing discourse"; they "[breed] vitriol and violence; in short [they have bred] Donald Trump" (Ott 2017, p. 62). The Beast's obsession with Twitter, in particular, is legendary. Indeed, its "life-form is inseparable from [Twitter]." The Beast "receives with a shudder waves of social and political static," and spews them "back out with a Twitter spasm, in a self-perpetuating cycle" (Massumi 2017; see further Ott and Dickinson 2019, pp. 59-92). All of which is to say that the Beast and its Twitter account form a particularly potent affective assemblage, one supremely "capable of plugging into desire, of effectively taking charge of desire" (Deleuze and Guattari [1980] 1987, p. 166). Whose desire, precisely, we shall shortly see.

The mouth that the media, in their manifold forms, have bestowed upon the Beast does not only talk big: "The Beast was given a mouth speaking boastful things and blasphemies" (kai blasphemias-Rev 13:5). The Beast blasphemes against the egalitarian values that incrementally, painfully, over many generations, had established a foothold, or at least a toehold, in large sectors of its nation, values venerated, held sacred, in those sectors. Adorning the Beast's multiple, self-contradictory heads, indeed, are "names of blasphemy" (13:1, KJV): racist, xenophobe, misogynist, sexual predator, homophobe, climate denier ... . The Beast relishes "trading in cartoonish exaggerations" of political incorrectness, "refracted through the distorting prism of a white hypermasculinity bloated to absurd dimensions" (Massumi 2017; see also Massumi 2018, pp. 98-99; Ott and Dickinson 2019, pp. 35-48). The Beast does not care that it is a cartoon rendition of itself. The Beast "is unafraid of being a cartoon because cartoon characters never die, they keep going long after mere humans would be destroyed" (Berlant 2016).

Although the Beast exudes noxious ideologies, however, polluting vapors from the bottomless abyss, the Beast is not, at base, an ideological animal. Although ideology still flourishes in the kingdom of the Beast, "often in the most virulent of forms, ... [i]t is now one mode of power in a larger field that is not defined, overall, by ideology" (Massumi 2002, p. 42). ${ }^{13}$ The appearance of coherence necessary to political ideology is discarded in the post-ideological moment, which Massumi (p. 41) sees as already emerging in the presidency of Ronald Reagan, who was "an idiocy musically coupled with an incoherence." With the rise of the Beast, however, even the musicality has fallen, with a discordant jangle, into the bottomless abyss.

Yet the Beast's inarticulate incoherence is essential to its mesmerizing power. Revelation 13:3 reads: "One of [the Beast's] heads seemed to have received a death-blow, but its mortal wound had been healed." Spectacular inability on the part of any human head to sound "presidential" - except briefly when reading (stumblingly) from a teleprompter-or even to utter two successive well-formed sentences would, prior to the ascent of the Beast, indeed have been a mortal wound, a deadly affliction, for the owner of the said head had he or she aspired to occupy the Oval Office. With a perpetually bandaged head and a mouth ever ready to spill over with absurdities, the Beast is the apocalyptic antitype of the classic presidential stateman.

"In amazement," nonetheless, "the entire earth follow[s] the Beast" (Rev 13:3)—on Twitter, on every news media outlet. Indeed, "all the inhabitants of the earth ... worship [the Beast]" (13:8; cf. 13:4,12) -or at least the Beast's indefatigable self-exaltation seems to assume that they should. That was why the Beast was momentarily taken aback when, on 25 September 2018, a wave of laughter erupted from the floor of the United Nations General Assembly Hall in response to the Beast's casual boast that the achievements of its administration already exceeded those of any other in the history of its nation. Although the Beast is fervently loathed by legions of its U.S. subjects, surprisingly little in

13 Massumi was not, of course, referencing Trump in this 2002 statement, but the Trump presidency might be regarded as the full flowering of post-ideological politics. In his first television interview after suspending his own presidential campaign, democratic socialist Bernie Sanders declared: "Donald Trump is a guy who has absolutely no ideology ... . His goal, his only goal is to win. To enrich his friends, he will say or do anything to do that." Ian Schwartz, "Bernie Sanders: Trump Has Absolutely No Ideology, I Would Not Drop Dead If He Proposed Medicare for All," RealClear Politics, April 9, 2020, https://www.realclearpolitics.com/video/2020/04/09/bernie_sanders_trump_has_absolutely_no_ideology_i_would_ not_drop_dead_if_he_proposed_medicare_for_all.html. 
the U.S. political or cultural arenas had prepared it for this spontaneous show of collective derision. Massumi writes of Reagan: "[W]hat is astonishing is that Reagan wasn't laughed and jeered [at]" (2002, p. 40). Oh, but he was, just not, or not so much, in the United States. Symptomatic of the general derision directed at Reagan in much of the world were his weekly appearances throughout his second term as a grotesque life-sized puppet on Spitting Image, the viciously satirical, and vastly popular, BBC show. Reagan was a figure of savage fun in Britain and beyond because he seemed to so many to be a vacuous imbecile, a ham actor of his own plastic persona.

With the Beast it's a little different. In 2016-2017, while campaigning for president and during its first year in office, it was lampooned regularly on Saturday Night Live. Since then, however, the Beast has largely faded from the show, notwithstanding the fact that it continues to provide rich fodder for satire on a weekly, if not daily, basis ("More than any other president in the history of our country-not even close," the Beast itself might be imagined to interject). But that is precisely the problem. The Beast flirts so continually with self-caricature as to render caricature by others all but redundant. The Beast reproduces hyperbolic versions of itself from moment to moment. The Beast is a simulacrum of itself. The Beast and "the image of the Beast" (Rev 13:14-15; 14:9, 11; 15:2; 16:2; 19:20; 20:4) are indistinguishable in terms of what they are and what they do. The Beast continually voids itself in order to be itself. "The Beast ... was, and is not," always about "to ascend from the bottomless abyss and go to destruction" (17:8; cf. 17:11)—before replicating itself yet again, resurrecting from the ruins of its own misrule. But the Beast is also horribly, dismally funny. In this regard, the current Beast, the incumbent Beast, is the best-equipped actor, of the exceedingly long line of actors (a parade of monarchs, popes, dictators, presidents, and sundry other dignitaries and despots), ever to actualize the virtual role of the Beast scripted in Revelation. "Not even close, not even close."

The drunken spectacle of "Babylon the great, mother of whores and of earth's abominations" (Rev 17:4-6) has been insufficiently recognized by scholars of Revelation as an ancient political cartoon, a savage satire, a comedic send-up of imperial Rome. Still less has the Beast from the bottomless abyss been recognized as such. ${ }^{14}$ Plug Donald J. Trump into Revelation's Beast machine, however, and gigantic gales of canned laughter (recorded in the UN General Assembly Hall) resound through the universe as he performs his abysmal stand-up schtick: "I was watching the other night the great Lou Dobbs [Fox television personality], and he said ... 'Trump is a great president.' [Anticipatory chuckles.] Then he said, 'Trump is the greatest president since Ronald Reagan.' Then he said ... , 'No, no, Trump is an even better president than Ronald Reagan!' [Guffaws and whoops.] And now he's got me down as the greatest president in the history of our country, including George Washington and Abraham Lincoln!'" [General unconstrained laughter.] ${ }^{15}$

The (Sea-)Beast's knee-slapping stand-up routine is further enlivened by the entrance of the hilariously humorless Second Beast: "Then I saw another beast that rose up out of the earth ..." (Rev 13:11). Who plays straight-man Land Beast to President Trump's Sea Beast? Why, Vice President Pence, of course. The function of the Land Beast, however, is not to cause "the earth and its inhabitants" to laugh at the First Beast so much as to "worship the First Beast" (13:12), and to paraphrase articulately the First Beast's inarticulate ramblings "so that the image of the Beast could even speak" (13:15). Vice-President Pence's Land Beast role was never more obvious than during the daily White House Coronavirus Task Force press briefings, which began in March 2020 and continued for six weeks, one part bizarre reality show (Trump repeatedly touting the ratings of the briefings on Twitter as "through the roof"_- "Monday Night Football, Bachelor Finale type numbers") ${ }^{16}$ and two parts surreal reelection rally ("Going to win. We're going to close it out ... . Look at us: We had the greatest

14 Both lacks have, however, now been remedied by Sarah Emanuel (2020, pp. 126-66).

15 Verbatim from a rally in Lexington, Kentucky on November 4, 2019, https://www.mediamatters.org/lou-dobbs/donald-trumpbrags-about-lou-dobbs-declaring-him-greatest-president-history-our-country. For incisive analysis of the Trump-Fox symbiosis as it intersects with white nationalism and white evangelicalism, see Keller (2018).

16 Donald J. Trump, Twitter posts, April 8-10, 2020, http://twitter.com/realDonaldTrump. 
economy in the history of the world ... . We had the highest stock market in history, by far. And I'm honored by the fact that it has started to go up very substantially. That's because the market is smart ... . And they're viewing it like we've done a good job .... We've done a fantastic job. We're the talk of other nations" $).{ }^{17}$ And the Land Beast's function in this unreal spectacle? The Trump reflected-reinvented in VP Pence's unctuous utterances at the briefings (the object of his obsequious effusions all the while hovering by his shoulder) was a pillar of wisdom, a fountain of compassion, and a beacon of guidance for his people: "Thank you, Mr. President. This day should be an inspiration to every American ... thanks to your leadership ... . Mr. President, from early on, you took decisive action ... . Mr. President, you have forged a seamless partnership with every state and every territory in this country to put the health of our nation first." 18

We should not be surprised; we should rather be amazed. For with uncanny aptness, Revelation declares "amazement" to be the primary affect ${ }^{19}$ engendered by the First Beast (as in: First Lady, First Family, First Beast): "In amazement the entire earth followed the Beast" (literally, "And the entire earth was amazed after the Beast" [kai ethaumasthē hole hē gē opisō tou thēriou]-13:3). This amazement is able to face in two directions at once, like two of the Beast's seven heads. It is the awed, true-believer wonder of those for whom the Beast is indeed the most stupendous president in the history of the United States ("In the history of the world, even," adds the Beast), or it is the drop-jawed, disbelieving astonishment of those who are still regularly stunned by what comes out of the Beast's mouth ("And I saw three foul spirits like frogs coming from the mouth of the Dragon, from the mouth of the Beast, and from the mouth of the False Prophet" - Rev 16:13).

The COVID-19 crisis is, of course, proving definitive for the Beast, revealing more than any previous event what the Beast "[is] and is not" (Rev 17:8,11). The Beast's name will now forever be linked with the novel coronavirus, the virus that takes its name from its crownlike structure. With impeccable logic, therefore, when the Beast is first described in Revelation, it is said to have multiple "crowns" (diadēmata) on its horns. Uncharacteristically, the current Beast does not want this regal adornment. It has tried repeatedly to shrug it off, shaking its many heads vigorously, each one voicing its own disavowal ("It's one person coming in from China. We have it totally under control"; "It will go away in April with the heat"; "Within a couple of days it's going to be down to close to zero"; "It's going to disappear. One day-it's like a miracle [conjuring hand gesture]—it will disappear" ... $){ }^{20}$ but to no avail. The Beast is stuck to it and stuck with it. The Beast may not (yet) have the virus, but the virus has the Beast by the horns.

The novel coronavirus early infected the contemporary reception of Revelation, as we saw, mutating into an apocalyptic event as it passed into the book and coursed through its body. How precisely did the virus affect, or infect, the Beast? Particularly pertinent here is Revelation 16:10, the fifth of the seven eschatological "plagues" (15:1, 6, 8) "pour[ed] out upon the earth" (16:16:1), as it is the plague that touches the Beast most directly: "The fifth angel poured out his vial [phialē] ${ }^{21}$ upon the throne of the Beast, and its kingdom was plunged into darkness." The throne of the Beast, the seat and source of its

17 Sample remarks culled from the White House Coronavirus Task Force Press Briefing of April 18, 2020, https:/www. whitehouse.gov/briefings-statements/remarks-president-trump-members-coronavirus-task-force-press-briefing-2/.

18 Representative remarks taken from the White House Coronavirus Task Force Press Briefing of March 13, 2020, https: //theconservativetreehouse.com/2020/03/13/transcipt-of-coronavious-task-force-press-conference/.

19 I use the term "affect" more loosely in this article than Deleuze or Massumi would. For Deleuze, as for Massumi following him, affect is logically prior to emotion (Massumi 2002, pp. 27-28). "Sensation" better captures affect in the Deleuzian sense (Deleuze 2003; see esp. p. 35 in which affect is equated explicitly with sensation), but it is a concept of sensation called to do much heavy philosophical lifting.

20 David Leonhardt, "A Complete List of Trump's Attempts to Play Down Coronavirus," The New York Times, March 15, 2020, https://www.nytimes.com/2020/03/15/opinion/trump-coronavirus.html.

21 Resurrecting KJV's translation of phiale as "vial" throughout Revelation (see also 15:7; 16:1-4, 8, 12, 17; 17:1; 21:9, together with 5:8). The term "vial," which, as it happens, derives from phiale, seems particularly apt in the current context, evoking for the modern ear-most of all the modern ear attuned to conspiracy theories-a divine laboratory in heaven where deadly chemical agents are concocted. 
globe-encircling power, is the economy it inherited, and this economy is what the coronavirus plague has paralyzed.

The kingdom that was plunged into darkness by the plague was an eschatological kingdom, the capitalist utopia toward which all human history had been tending. "I built the greatest economy in the history of the world," the Beast boasted at the Coronavirus Task Force press briefing of April $27,2020.22$ "No one [could] buy or sell" in that utopia "who did not have the mark ... of the Beast" (Rev 13:17), for they all owed their prosperity to the Beast, as the Beast saw it. But then the plague came, that "great and powerful Plague." ${ }^{23}$ The Beast publicly mourned the death of the eschatological economy and prayed for its resurrection, envisioning it emerging radiant from the tomb on Easter Sunday hand in hand with the risen Jesus: "I would love to have it open by Easter ... . It's such an important day for other reasons, but I'll make it an important day for this, too. I would love to have the country opened up and just raring to go by Easter."24

As the personification of capital, the Beast was affectively equipped to feel wrenching loss, searing grief, only at capital's demise. In the Task Force press briefings, it did not even pretend to be affected by the virus's escalating death toll. On the rare occasions it mentioned that toll, already exacted or still impending, individual lives tended to be rolled into the impersonal abstraction "death" and the delivery tended to be flat and emotionless: "And there will be a lotta death, unfortunately, but a lot less death than if this wasn't done [the Beast's 'China ban'], but there will be death." ${ }^{25}$ As Lauren Berlant (2017a, p. 16) has observed in a different context, "[Affective] flatness is different than lack. It is not only a subtraction, but a form of performance, a style of showing up." Who or what was showing up in the Beast's flat death prediction, what other monster was performing on that occasion-besides the "corpse-green horse [whose] rider's name was Death" and who had been "given authority over a fourth of the earth to kill with ... pestilence" (Rev 6:7-8)? The many-tentacled monster of systemic racism, perhaps? Even as the Beast pronounced its "lotta death" sentence, African American communities were, at grotesquely disproportionate rates, bearing the brunt of the COVID-19 death toll across the United States. $^{26}$

What in sum, then, is the Trump machine, the Beast machine, and what precisely does it do? It is a mouth, mainly, as we have seen ("The Beast was given a mouth ... "- - Rev 13:5), an organic mouth and an electronic mouth. This mouth brags constantly (" ... speaking boastful things"-13:5) and lies continually. Through its fabrications, legendary in their profusion, it produces its own habitat, one in which it is an object of worship for its followers: "They worshiped the Beast, saying, "Who is like the Beast ... ?'" (13:4). The Beast nods all of its seven heads sagely and retweets approvingly ("Thank you for the very nice words ... . Wow!") an effusion by an especially devout follower declaring the Beast to be "the King of Israel" and "the second coming of God." That same day the Beast announces on the north lawn of the White House, while looking up to heaven, "I am the Chosen One."27

The Beast is also a political paradox of the first order. On the one hand, the Beast uniquely embodies the telos of democracy, the election to the most powerful political office on the planet of someone who might as well have been plucked at random from the demos, the people, milling in the street (Wall Street, anyway, if not yet Main Street), so spectacularly unqualified is he to assume the immensely consequential responsibilities of that office. On the other hand, and by the same

22 From the transcript: https://www.democraticunderground.com/10021335936.

23 Donald J. Trump, Twitter post, May 3, 2020, 10:43 a.m., http://twitter.com/realDonaldTrump.

24 Quint Forgey et al., "'I'd Love to Have It Open by Easter': Trump Says He Wants to Restart Economy by Mid-April," Politico, March 24, 2020, https://www.politico.com/news/2020/03/24/trump-wants-to-restart-economy-by-mid-april-146398.

25 “There Will Be a Lot of Death': Trump Warning as COVID-19 Cases in US Pass 3000,000," The Guardian, April 5, 2020, https://www.theguardian.com/world/video/2020/apr/05/there-will-be-a-lot-of-death-trump-warning-as-covid-19cases-in-us-pass-300000-video.

26 For details, see "The Color of Coronavirus: COVID-19 Deaths by Race and Ethnicity in the U.S.," APM Research Lab, May 27, 2020, https://www.apmresearchlab.org/covid/deaths-by-race.

27 Kevin Breuninger, "I Am the Chosen One,' Trump Proclaims as He Defends Trade War with China," CNBC, August 21, 2019, https://www.cnbc.com/2019/08/21/i-am-the-chosen-one-trump-proclaims-as-he-defends-china-trade-war.html. 
token, the Beast's election emblematizes the final failure of democracy, the erosion of its values and institutions, its potential slippage back into the bottomless abyss where the Beast has its lair and out of which every cruel, capricious, or deranged despot in history had crawled-until democracy stepped in to put an end to dynastic games of chance that could put a monster or a moron on the throne.

What is the reason for the Beast's astonishing success? What is the Beast, exactly, for its followers? What precisely does it enable them to be and do? And how has that being and doing been affected, and infected, by COVID-19?

\section{Affective Politics in a Time of Plague}

Trumpmania is itself an infection. Consider the Beast at its most iconic, towering above the throng at a rally, whipping it into a frenzy. As Michael Richardson (2017, p. 752) notes, "Crowds are affective formations ... , particularly susceptible to contagion, the leaping of affect from body to body" (cf. Gibbs 2008, p. 133; Connolly 2017, pp. 15-18), not least the crowd at a Trump rally. The latter is a particularly arresting example of what Lauren Berlant (2011, p. 226) has termed "an intimate public": an "affect world" in which "matters of survival" are urgently at stake. "You do not need to audition for membership in [an intimate public]. Minimally, you need just to perform audition, to listen," and to open yourself fully to the "visceral impact" of that highly charged space (p. 226). This is not to imply that members of the specific intimate public that is the Trump rally have no active role to play in it. For it is not the Beast that roars at the rally, but rather the crowd that is an active extension of the Beast's will. And what does the crowd roar? "[I]ncantations of containment and control," as Richardson (2017, p. 752) observes: “Build that wall!" “Lock her up!" “Send her back!"28

As it happens, an impressively high wall bisects the final two chapters of Revelation. The book's climactic vision is set in a divinely designed gated community, a heavenly walled enclave. The heavenly city that descends to earth in this culminating vision is surrounded by a high wall ("It has a great, high wall"-21:12) — “one hundred forty-four cubits" high (21:17), ${ }^{29}$ to be precise, which translates to around two hundred and sixteen feet, a height far exceeding even the Beast's most ambitious dreams for its own wall: "I will build a great wall, and nobody builds walls better than me, believe me ... . I will build a great, great wall." 30 Like the Beast's wall, designed to exclude anathematized ethnic others ("You wouldn't believe how bad these people are. These aren't people. These are animals"), ${ }^{31}$ the heavenly city's wall is also designed to shut out undesirables, including animalized others: "Outside are the dogs [hoi kynes] $]^{32}$ and sorcerers and fornicators ..." (22:15).

Plugging the Revelation machine into the Trump machine causes the latter to light up but it also causes the former to malfunction. Circuits are scrambled and components melt into each other. Within the Revelation-Trump megamachine, God is no longer the only builder of a wall; the Beast

28 Hillary Clinton has been the most frequent target of the Trump rally "Lock her up!" chant. In July 2019, Democratic congresswoman Ilhan Omar, an outspoken Trump critic and a U.S. citizen who had come to the country as a child refugee from Somalia, became the target of the "Send her back!" chant. A "Send them back!" chant also flourished briefly during this period, three other Democratic congresswomen of color, Alexandria Ocasio-Cortez, Ayanna Pressley, and Rashida Tlaib, all born in the U.S., being grouped with Omar as its target. Trump had earlier tweeted: "So interesting to see 'Progressive' Democrat Congresswomen, who originally came from countries whose governments are a complete and total catastrophe, the worst, most corrupt and inept anywhere in the world (if they even have a functioning government at all), now loudly and viciously telling the people of the United States, the greatest and most powerful Nation on earth, how our government is to be run. Why don't they go back and help fix the totally broken and crime infested places from which they came?" Donald J. Trump, Twitter post, July 14, 2019, 8:27 a.m., http://twitter.com/realDonaldTrump.

29 Or wide, a position taken by some scholars, although the majority read "he also measured its wall, one hundred forty-four cubits" as a designation of height. See, e.g., Beale (1999), pp. 1076-77; Blount (2009), p. 390.

30 William Cummings, "'A Wall Is a Wall!' Trump Declares," USA Today, January 21, 2019, https://www.usatoday.com/story/ news/politics/onpolitics/2019/01/08/trump-wall-concept-timeline/2503855002/.

31 Gregory Korte and Alan Gomez, "Trump Ramps Up Rhetoric on Undocumented Immigrants," USA Today, May 17, 2018, https://www.usatoday.com/story/news/politics/2018/05/16/trump-immigrants-animals-mexico-democrats-sanctuarycities/617252002/.

32 A term some critical scholars of Revelation have interpreted as denoting homosexuals. For examples and discussion, see Thomas (2018), pp. 94-97. 
becomes obsessed with building its own wall, and would love nothing better than to build it to an ungodly height. But this ambition is part of a larger disintegration. Pre-Trump Revelation construct God and God's empire as rigidly regulated by purity codes. The symbolic lines of separation in Revelation run obsessively between the clean and the unclean, the undefiled and the polluted, the pure and the impure, the unmixed and the hybrid (e.g., 3:4-5; 7:14b; 14:4-5; 19:8, 14; 21:27; 22:14-15). The pre-Trump Beast, its proxies, and its entire empire, in absolute contrast, are a seething morass of cultic impurity, of cultural hybridity, of cultural assimilation (e.g., 2:14, 20-21; 17:4-5; 18:2). ${ }^{33}$ But when the Revelation machine is plugged into the Trump machine, the separatist imperative ("Come out of her, my people"-18:4) passes into the Beast like an electric charge, and the Beast itself becomes an uncompromising custodian of purity.

For as Richardson (2017, p. 747) perceives, "Walls and bans are not simply policies of exclusion, but of purity." Their function is to "harden the lines" (p. 748) between one culture conceived as preeminent, privileged, and pristine-in a word, as white ("I saw a great white throne" - Rev 20:11) —and other cultures conceived as inferior, polluted, and defiling. "Why are we having all these people from shithole countries come here?" rages the Beast. ${ }^{34}$ In short, the purpose of walls and bans is to "[prevent] transmission that might ... infect the homeland" (Richardson 2017, p. 748).

Richardson's use of epidemiological metaphors for Trumpism here and elsewhere in his article, published before COVID-19, acquires added significance from it. Richardson (2017, p. 751) sums up the Trumpian white nationalist mindset as follows: "If the economy is sick, if communities are sick, if life is just different now, then it must be because some impurity has crossed over. All too often, this is an impurity embodied by the other who looks, speaks or acts differently." In the transformed social world ushered in by COVID-19-a world in which life is undeniably different, in which communities and the economy are desperately ill-the Beast has instinctively seized on the virus as a potent metaphor for the cultural crisis, the existential threat, that undocumented, non-white immigrants, migrants, asylum seekers, and refugees embody in its xenophobic demagoguery.

In an Oval Office address to the nation on March 11, 2020, the Beast described COVID-19 as the "foreign virus." 35 A few weeks later, as we have already seen, the Beast was repeatedly referring to the pandemic as "the plague." These two characterizations of COVID-19 appear to be intimately interlinked in the Beast's psyche. ${ }^{36}$ Pre-COVID-19 and for the pre-presidential Beast, Ebola was the plague. Attempting to stoke (white) hysteria during the West African Ebola outbreak of 2014 to 2016 , the Beast grimly warned that unless the United States banned flights from the region, "the plague will start and spread inside our "borders"'37 (derisive quotation marks around "borders" regarded as too porous to protect against contamination). And when President Obama sent a military force to Liberia

33 The first scholars of Revelation to recognize the extent of its preoccupation with purity were David Frankfurter (2001, esp. pp. 410-12) and John W. Marshall (2001, esp. pp. 155-62).

34 Leighton Akio Woodhouse, “Trump's 'Shithole Countries' Remark Is at the Center of a Lawsuit to Reinstate Protections for Immigrants," The Intercept, June 28, 2018, https://theintercept.com/2018/06/28/trump-tps-shithole-countries-lawsuit/. Compare the following statement by Trump's former attorney Michael Cohen: "He [Trump] once asked me if I could name a country run by a black person that wasn't a 'shithole."' From Cohen's testimony to the Committee on Oversight and Reform of the U.S. House of Representatives, February 27, 2019, https://www.theguardian.com/us-news/2019/feb/27/fulltext-michael-cohen-statement-to-congress.

35 Paul LeBlanc, “Trump Calls Coronavirus a 'Foreign Virus' in Oval Office Address," CNN, March 11, 2020, https://www.cnn. com/2020/03/11/politics/coronavirus-trump-foreign-virus/index.html. Trump has also described COVID-19 more specifically as the "Chinese virus"-more than twenty times over a two-week period in March, 2020-catalyzing a rash of racist acts against Asians within the United States (see "Donald Trump's 'Chinese Virus': The Politics of Naming," The Conversation, April 21, 2020, https://theconversation.com/donald-trumps-chinese-virus-the-politics-of-naming-136796).

36 Both characterizations combine explicitly in Trump's commencement address to the United States Military Academy at West Point, New York on June 13, 2020: "I want to take this opportunity to thank all members of America's Armed Forces ... who stepped forward to help battle the invisible enemy, the new virus that came to our shores from a distant land called China. We will vanquish the virus, we will extinguish this plague." "Donald Trump West Point Commencement Speech Transcript," https://www.rev.com/blog/transcripts/donald-trump-west-point-commencement-speech-transcript.

37 Quoted in (Pitney 2020, p. 62). 
to build healthcare facilities and train medical personnel, the Beast exclaimed: "Why are we sending ... soldiers into Ebola infested areas of Africa! Bring the plague back to U.S.?" (in Pitney 2020, p. 62).

"Outside are the dogs," Revelation's Jesus declares of the book's eschatological wall (22:15). ${ }^{38}$ "Outside are the vermin," the Beast might declare of its own desired wall. "Infest," "infested," and "infestation" have always been ready terms of contempt for the Beast when speaking about people of color. Democrats "want illegal immigrants ... to pour into and infest our Country" (in Pitney 2020, pp. 62-63). The predominantly African American Baltimore district of late congressman Elijah Cummings "is a disgusting, rat and rodent infested mess" (p. 63), as is the Atlanta district of African American civil rights icon and congressman John Lewis. ${ }^{39}$ Sanctuary cities that harbor undocumented immigrants are "crime-infested" and "breeding" sites. ${ }^{40}$ The four congresswomen of color who are critical of the Beast's policies should "go back" to the "crime infested places from which they came." 41 And so on. All of it amounts not just to an animalization of the racial other, ${ }^{42}$ but to a $^{2}$ verminization of the racial other. And vermin are carriers of plague. This is a particularly virulent example of what Gerald V. O'Brien $(2018$, p. 2) has termed "the organism metaphor," 43 a means "for denigrating vulnerable populations" that feeds on visceral revulsion at the possibility of one's physical or social body being invaded by aliens, parasites, germs, or other creatures of nightmare. The organism metaphor, deployed against "immigrants and other 'foreign' bodies," exploits this primal horror rhetorically.

The perceived infestation of the vermin causes worshipers of the Beast to "gnaw their tongues in agony" and "curse God" because of their imagined "pains and sores," as Revelation reports when the fifth plague-bowl (a bowl of vermin?) is "poured out," the one that lands directly "on the throne of the Beast" (16:10-11). The intolerable sensation of the vermin skittering across its flesh, entering the orifices of its body, the unbearable feeling of being invaded, of being contaminated, causes the Beast itself to descend into madness on national television, climbing naked into its sunbed while clutching a bottle of disinfectant and a syringe:

So supposing we hit the body with a tremendous-whether it's ultraviolet or just a very powerful light.... And then ..., supposing you brought the light inside the body, which you can do either through the skin or some other way .... I see the disinfectant that knocks it out in a minute, one minute. And is there a way we can do something like that by injection inside or almost a cleaning? As you see, it gets in the lungs, it does a tremendous number on the lungs, so it would be interesting to check that. ${ }^{44}$

But enough of madness. How, more precisely, does the Beast react to vermin, to plague, and to every other perceived source of infestation or infection? It is time to take a deep breath and push our way back into the Trump rally we left earlier. The chants of "Build that wall!," "Lock her up!," and "Send her back!" are still resounding. Such chants are "rituals of purification" (Richardson 2017,

38 Taking Jesus to be the speaker of Rev 22:14-15 (see Koester 2014, p. 841).

39 Doug Criss, "Atlanta Hasn't Forgotten That Trump Called It 'Crime Infested' and in 'Horrible Shape,'” CNN, January 9, 2018, https://edition.cnn.com/2018/01/08/politics/trump-atlanta-trnd/index.html.

40 Z. Byron Wolf, “Trump Blasts 'Breeding' in Sanctuary Cities. That's a Racist Term," CNN, April 24, 2018, https://www.cnn. com/2018/04/18/politics/donald-trump-immigrants-california/index.html.

41 See n. 28 above.

42 Congressman Cummings's district is a place where "no human being would want to live." Earlier, an economically disadvantaged area of Chicago through which Trump was being driven elicited the comment "that only the blacks could live like this" (Emily Jane Fox, "Michael Cohen Says Trump Repeatedly Used Racist Language Before His Presidency," Vanity Fair, November 2, 2018, https://www.vanityfair.com/news/2018/11/michael-cohen-trump-racist-language, a claim reiterated in Cohen's testimony to the Committee on Oversight and Reform of the U.S. House of Representatives, February 27, 2019, https://www.theguardian.com/us-news/2019/feb/27/full-text-michael-cohen-statement-to-congress).

43 Although without reference to Trump or his infestation trope.

44 Dartunorro Clark, “Trump Suggests 'Injection' of Disinfectant to Beat Coronavirus and 'Clean' the Lungs," NBC News, April 24, 2020, https://www.nbcnews.com/politics/donald-trump/trump-suggests-injection-disinfectant-beat-coronavirus-cleanlungs-n1191216. 
p. 750), and the affect impelling and expelling them is disgust. ${ }^{45}$ For the Beast is a creature of disgust, not only in the sense that its words and actions disgust untold numbers of people in its own kingdom and around the world, but in the sense that it is driven by disgust. It is disgusted by the porousness, the leakiness, the messiness of bodies, both human and national.

First, the human body. Since entering U.S. politics, Donald Trump has, to cull some of the more notorious examples, publicly expressed revulsion at the perspiration of a male political opponent and the mastication of another; the menstrual blood of a female debate moderator; and the urine of a female political opponent. ${ }^{46}$ Specifically, Trump described Florida senator and presidential candidate Marco Rubio's perspiration as "disgusting" (also applying a telling epidemiological diagnosis to it: "We need somebody that doesn't have whatever it is that he's got!"), and said of another presidential rival, former Ohio governor John Kasich, "I've never seen a human being eat in such a disgusting fashion" (ergo, Kasich is subhuman, like every other object of Trump's disgust: "Do you want that for your president? I don't think so!"). Trump declared of Fox News anchor Megyn Kelly: “There was blood coming out of her eyes, blood coming out of her wherever." Ironically, this was Trump's characterization of the following statement made to him by Kelly, part of a question she was addressing to him at the first Republican presidential debate of 2015, in which she was the sole female moderator: "You've called women you don't like fat pigs, dogs, slobs, and disgusting animals."

Most telling of all, Trump commented on Hillary Clinton, when she took a bathroom break during a Democratic presidential debate: “I know where she went, it's disgusting, I don't want to talk about it. No, it's too disgusting. Don't say it, it's disgusting, let's not talk." This pleonastic outburst of gynophobic revulsion also plugs magnetically into Revelation. For Hillary Rodham Clinton, even before she became the Democratic nominee for President of the United States, was a leading candidate for the "whore of Babylon" role in Revelation. As biblical critic Timothy Beal (2018, pp. 138-39) remarks, even a cursory internet search reveals that the Hillary-"Great Whore" identification gives lurid expression "to masculine anxieties about powerful women." Acute anxiety in general, as affect theorist Eugenie Brinkema (2014, p. 187) notes, "writhes, roils, and shudders, makes the flesh creep away from the self in a quick, lively flaying." Masculine anxiety, specifically, causes male phalluses to shrivel alarmingly and breeds gynophobic disgust as a countervailing force and violent repudiation: "Such a nasty woman!"47 Small wonder, then, that "the Beast will loathe [misēsousin] the Whore," and, in its imagination at least, it and its lackeys "will ravage her and strip her naked [kai èrēmōnenēn poièsousin autēn kai gymnēn], and they will devour her flesh and burn her with fire" (Rev 17:16; cf. 17:12). ${ }^{48}$

What of the U.S. national body? The Beast has, as we have seen, repeatedly expressed disgust at what-or, more precisely, who-he perceives as infecting infestations of that body, the swarms of subhuman vermin pouring into it like a plague. The Beast's reflexive gesture in the face of such perceived contamination has always been one of warding off, of shutting out. Measures designed to turn back the influx of non-white immigrants and refugees ("my beautiful wall," "my Muslim ban") have more recently been supplemented by measures designed to turn back the influx of viral infection by excluding those whom the Beast has branded the virus's most deadly carriers ("my China ban"). The two primary meanings of "plague," literal and metaphorical, thereby coalesce in the Beast's visceral rhetoric of revulsion. The virus ("I call it the invisible enemy") ${ }^{49}$ becomes a metaphor in that rhetoric for undocumented non-white immigrants or migrants (whom the Beast apparently considered

45 Disgust, most especially collective disgust, is a violent emotion. "In fixing its object as 'intolerable,' disgust undeniably has been and will continue to be instrumentalized in oppressive and violent ways" (Ngai 2005, p. 340; see further Ahmed 2014, pp. 82-100).

46 Examples assembled and documented in both Hurst (2015) and Richardson (2017), p. 747.

47 Trump's infamous putdown of Clinton, uttered with deliberate audibility during the final presidential debate of 2016 as she criticized his policy on social security.

48 Moore (2014), pp. 155-78 explores the convulsive movements of gendered disgust in Revelation.

49 A Trump refrain during the White House Coronavirus Task Force press briefings. 
labeling "enemy combatants" at one time). ${ }^{50}$ More precisely, the migrant plague is metamorphosed (cf. Deleuze and Guattari 1986, p. 22) into the virus plague within the belly of the Beast ("I have a gut, and my gut tells me more sometimes than anybody else's brain can ever tell me") ${ }^{51}$ and transmitted, thus transmuted, from its mouth, without ever having passed through its conscious mind.

What is transmitted through that mouth—the "mouth given to" the Beast (Rev 13:5)—is infection, for the Beast's disgust is highly contagious, a pandemic in itself. Trump's fervent followers open themselves up to their leader's disgust, allow themselves to be infected by it, and flood him with their own disgust in turn, in a continuous politico-epidemiological loop. The followers feel with the leader, and while so many non-followers are disgusted by him, they are disgusted with him (Richardson 2017, p. 753), channeling their revulsion through his, and feeling it flow back into them in a process of circulation that is the lifeblood of the national body they crave, fantasized as a decontaminated body. That is why Trumpism is a secular religion of purification and why the Beast is an addictive object of worship for its most ardent followers: "And they [worship] the Beast saying, 'Who is like the Beast, and who can fight against it?"' (Rev 13:4). To which the Beast replies, "There's nobody like me. Nobody" (Trump 2015, p. 74).

\section{Horrible Hope}

The Beast may be regarded as a consummate object of what affect theorist Lauren Berlant has termed cruel optimism - so much so, indeed, that her 2011 book of that title reads at times like a secular prophecy of the rise and reign of the Beast..$^{52}$ As she explains (p. 1), "A relation of cruel optimism exists when something you desire is actually an obstacle to your flourishing. It might involve ... a kind of love; it might be a fantasy of the good life, or a political project." Such optimism becomes cruel "when the object that draws your attachment actively impedes the aim that brought you to it initially." In the case of the Beast and its followers, that the latter were drawn to the former in the first place, that they so fervently put their hope in it, is an enigma to those who do not themselves bear "the mark ... of the Beast or the number of its name" (Rev 13:17). "By what criterion," muses Massumi (2017), "is there an identity or sameness between a billionaire born into wealth and privilege and a middle American in the Rust Belt with the fear of God in them about falling into poverty (if they are not already in it)?"53 But as Massumi also recognizes, it is not identification as mimesis that fuels the Trump machine so much as identification as immersion. His followers do not identify with him so much as immerse themselves in what flows through him—in "capitalism's deregulated overspilling of the norms," in "'politically incorrect' excess over regulated norms of behavior," 54 in a fantasized "exceptionalism" experienced as a continuous consolidation of their Americanness over against all

50 So Anon (2019), p. 42: "If we said these illegals were a national security threat, Trump reasoned, then the administration had an excuse to keep all of them out of the country." The anonymous author of this lid-lifting book credibly claims to be a senior official in the Trump administration.

51 Sarah Zhang, “Trump's Most Trusted Adviser Is His Own Gut,” The Atlantic, January 13, 2019, https://www.theatlantic.com/ politics/archive/2019/01/trump-follows-his-gut/580084/.

52 The reigning U.S. president when the book was published was, of course, Barack Obama, and although Berlant only devotes a single paragraph to his presidency, he is a felt presence in much of the remainder of the book. Berlant writes (2011, p. 228) of "the election of Barack Obama as the President of the emotional infrastructure of the United States as well as its governing and administrative ones," and asks: "What is the effect of Obama's optimization of political optimism against the political depression of the historically disappointed, especially given the President's limited sovereignty as a transformative agent in ordinary life? ... Splitting off political optimism from the way things are can sustain many kinds of the cruelest optimism."

53 Even the apparent physical sameness is an illusion, as Carleigh Morgan (2017) argues: "Trump looks as fit as the average American," but the corporeal resemblance is mere "hallucination." Trump's body is "the product of a lifestyle of luxurious, conspicuous excess .... . [He] has never been in the position of foregoing diabetes medication due to rising medication prices; has never had to settle for junk food while living in an economically depressed food desert littered with high fat, high salt, edible detritus; he does not know what it is like to stitch up his own lacerated hand because the thought of incurring several thousand dollars in Emergency Room bills might provoke yet another psychic and physical trauma .... [H]e is a fake body attached to a simulated image."

54 Cf. Berlant (2016): "You watch him calculating, yet not seeming to care about the consequences of what he says, and you listen to his supporters enjoying the feel of his freedom." 
non-Americans and, even more, all "un-American Americans": "'liberal progressives,' the 'mainstream media,' the 'deep state' establishment, immigrant 'job-stealers,' 'entitled' African Americans," and so on (Massumi 2017).

The hope invested in the Beast feels, for many of its followers, like a desperate hope, a last hope. Berlant's words (2011, p. 24), written before the rise of the Beast, are again apt: "Cruel optimism is the condition of maintaining an attachment to a significantly problematic object, [such] that the loss of the promising object ... itself will defeat the capacity to have any hope about anything." But incapacity to have any hope about anything, ever again, is no less a life or death issue for foes of the Beast, and it hinges no less than for its followers on the Beast's ultimate victory or defeat. For the legions of those within the United States for whom Trump is an abomination, the significantly problematic object might be the dream that he be defeated in the 2020 presidential election-significantly problematic because Trump, whatever outrages he utters or enacts, can never be pronounced politically dead, his many "mortal wounds," all apparent "death-blows," somehow being "healed" (Rev 13:3, 12) over and again, as his election as president in the first place demonstrated. And so devastating might be the loss of that promising object-someone else, anyone else, in the White House-as to defeat utterly thereafter the capacity of the Beast's foes to have any hope about anything, politically speaking. Optimism on either side of the political divide in this instance might be equally cruel.

What happens when we plug the book of Revelation into "the emotional infrastructure" (Berlant 2011, p. 228) of cruel optimism? What does Revelation, thus connected, have to say about hope? Nothing whatsoever, to the extent that neither the Greek verb nor noun for "hope" (elpizo, elpis) make an explicit appearance in it. Revelation is utterly without hope in this sense. Implicitly, however, Revelation is animated by a hope so audacious as to be all but delusional. Translated into the fraught political terms of the 2020 U.S. presidential election, Revelation's hope is that the incumbent Beast, the one with "a mouth like a lion" (Rev 13:2), would be thoroughly defeated-and defeated, what is more, not just by another white, cisgendered, heterosexual male, but by a brown-skinned challenger (with skin "like burnished bronze [homoioi chalkolibanō]"-1:15) ${ }^{55}$ who is also a trans person (dressed "with a golden sash across their [female] breasts [pros tois mastois]"-1:13), ${ }^{56}$ and whose answer to the stock grade-school question, "What animal would you most like to be?," would not be the answer favored by cisgendered little boys, "I'd like to be a lion!," but the altogether queerer answer, "I'd like to be a lamb!" (thinking to behold yet another would-be lion, the author of Revelation is surprised to see a lamb instead-5:5-6). "It is better to live one day as a lion than one hundred years as a sheep," is the Beast's contemptuous response. ${ }^{57}$

Donald Trump losing the presidency to a trans person of color (even if any such person were running)? Impossible? Undoubtedly. Apocalyptic hope, however, does not trade in the possible but in the virtual, in the Deleuzian sense: "The possible is opposed to the real ... . By contrast, the virtual is not ... ; it possesses a full reality by itself" (Deleuze 1994, p. 211). The reality of the virtual is particularly evident in the work of art, including the literary work, which, of course, is what Revelation is. Appropriating Deleuze and Guattari's statements about art, we might say that Revelation "incorporates" virtuality and thereby creates "a universe" for it in which it may possess "a life" (Deleuze and Guattari 1994, p. 177). More precisely, Revelation creates “a bloc of sensations" (pp. 167, 176), a mass of affects, which actualize themselves in communities of readers and liturgical audiences. More specifically still, Revelation "confides to the history of the future the persistent sensations that embody ... suffering" (e.g., Rev 2:10, 13; 6:9; 7:14; 13:15; 17:6; 18:24; 20:4) together with "protestation"

55 And hair like "wool" (erion). These anatomical details in Revelation's head-to-toe description of the risen Jesus (1:12-16) have long been of interest to people of African descent (see further Blount 2007, pp. 526-27; Ogbar 2004, p. 155).

56 These female breasts featured unapologetically in the Latin Vulgate and early English translations of the Greek New Testament (Wycliffe, Tyndale, Douay-Rheims, Bishops' Bible, KJV), but were quietly transformed into a manly chest in twentieth-century English translations (see further Rainbow 2007; Moore 2014, pp. 149-53).

57 Unacknowledged Mussolini quotation in Donald J. Trump, Twitter post, February 28, 2016, 6:13 a.m., http://twitter.com/ realDonaldTrump. 
and "struggle" (Deleuze and Guattari 1994, pp. 176-77). All of which is to say that apocalyptic hope is less an attainable hope, plausibly possible, umbilically linked to the question "Can it happen?," than a virtual hope, umbi(b)lically linked to the question "Can it be imagined?," and operating through affects to produce effects that are experienced as real. One generation's unimaginable, moreover ("A black man as U.S. president? Right. Why not give him an African name for good measure?"), becomes a subsequent generation's actuality, hope holding the virtual door open in the face of patent impossibility: "After this I looked and behold, a door had been opened in heaven!" (Rev 4:1).

But there is also another side to hope in Revelation, a side altogether less buoyant, weighed down by something more akin to hopelessness. And it is this obverse side of Revelation's double-sided version of hope that connects with the COVID-19 pandemic. Leading ecocritic of Revelation Barbara R. Rossing (2007) reports in the preface to the paperback edition of her academic bestseller The Rapture Exposed - whose subtitle, not coincidentally, is The Message of Hope in the Book of Revelation-that on the day the original edition was released, she was asked on $A B C$ World News Tonight "to say in seven seconds why [she] consider[s] Left Behind theology so dangerous," to which she replied: "God is coming to heal the world, not to kill millions of people" (2007, p. vii; cf. LaHaye and Jenkins 1995). This is Rossing's anti-dispensationalist counter-reading of Revelation, her construal of its "message of hope." Arguably, however, Revelation's message of hope is more incoherent than Rossing recognizes, better expressed as two disjointed statements rather than one unified statement: God is coming to heal the world. God is coming to kill millions of people. For a countless multitude of nameless people do die in Revelation due to the relentless succession of divinely willed disasters unleashed against the earth and its inhabitants (e.g., 6:3-4, 7-8; 9:13-19; 14:20; 19:11-21; 20:7-9). ${ }^{58}$

These two disjointed statements, wheeling around each other in midheaven (cf. Rev 19:17) and failing to conjugate, might be said to constitute a message of horrible hope appropriately fitted to our time of plague. For hope, even when it survives, is a shrunken emotion in such a time. Hope in a time of plague is itself infected by horror, not least the horror, the obscenity, of systemic racism, as we noted earlier, Americans of color, most of all black Americans, dying from COVID-19 at disproportionate rates relative to white Americans. On March 30, 2020, horrible hope, its racial underbelly concealed, was embodied in the benign person of Dr. Deborah Birx, become "America's doctor" by then, together with Anthony Fauci, due to their highly visible roles on the White House Coronavirus Task Force. Positively beaming with earnestness, Dr. Birx informed the nation: "If we do things together well, almost perfectly, we could get in the range of a hundred thousand to two hundred thousand fatalities. ${ }^{\prime 59}$ This is hopeless hope. ${ }^{60}$ This is hope in a time of apocalypse, and it is consonant with hope in the Apocalypse. For Revelation is not entirely without hope, as we have seen, but its hoped-for surcease from suffering lies on the other side of mass death on such a scale as to render that hope utterly horrible-so horrible as to silence altogether the utterance of the word "hope" in the book.

And what of the Beast in relation to the specter and spectacle of mass death? In the midst of the pandemic, the Beast stood up and boasted that it had stood in the breach and beat back the worst of the plague, not permitting it to vent the full measure of its wrath (“... seven angels with seven

58 Rossing argues that the calamities in question are directed, not at the earth, but rather at the Romans who exploit the earth (see Rev 11:18, together with Rossing 2002, 2005). She does not, however, adequately address the problem of collateral damage-loss of life, both human and nonhuman-which, like so much else in Revelation, is colossal in scale.

59 Ben Kesslen, “Dr. Birx Predicts Up To 200,000 U.S. Coronavirus Deaths ‘If We Do Things Almost Perfectly,'” NBC News, March 30, 2020, https://www.nbcnews.com/news/us-news/dr-deborah-birx-predicts-200-000-deaths-if-we-do-n1171876. The United States passed the 100,000 mark on May 27, less than two months after Dr. Birx's prediction.

60 It does not easily fit into the taxonomy of hope with which Ben Anderson's pre-COVID-19 book Encountering Affect begins. For Anderson (2014, p. 4), hope as affect may be "an object-target," as "in the example of consumer confidence"; it may be "a bodily capacity," as in the case of a rescue of trapped miners; and it may be "a collective condition" as it was "at Obama's inauguration" (although we might equally say, as it is at a Trump rally). Dr. Birx's prediction, and the equally grim prognostications of her Coronavirus Task Force colleague Dr. Fauci, seem in their data-and-model-driven aspect to participate in the first kind of hope; in their visceral life-or-death aspect to participate in the second kind; and in their "we're all in this together" aspect to participate in the third kind-while also seeming to elude or exceed all three categories. 
plagues, which are the last, for with them the wrath of God is ended"- $-\operatorname{Rev} 15: 1$ ) upon the American people. "In every way the best economy in the history of the world," the Beast began yet again. But the Beast shut down the eschatological economy, it proceeded to explain, because if it had not been willing to sacrifice, to slay, what it most loved, "we would have lost two million, two and a half million, maybe more than that, people," whereas now the losses amounted only to "two Yankee stadiums of people" (and, the Beast did not add but could almost be imagined doing so, about three-quarters of the people packed into those stadiums were blue state Democrats, anyway, who were not there to cheer for the Beast, much less vote for it). ${ }^{61}$ And earlier the Beast claimed to have saved the entire nation, if not the entire planet, from nuclear annihilation, declaring with reference to North Korea: "Look, if I wasn't elected, you would right now-maybe the world-would be over." 62

The Beast, then, is what holds the apocalypse at bay. Yet the Beast is also what is precipitating the apocalypse - the apocalypse of democracy, its incremental self-dismemberment, its inexorable regression to the despotism, the bottomless abyss, out of which it originally crawled. For what, after all, is the Beast? What would we actually behold if, like John of Revelation, we were empowered to ascend, if not to the heavenly throne room (Rev 4:1-2), then at least to the Oval Office, to hover outside its bulletproof windows and observe its current occupant, long after all his courtiers have been dismissed for the evening, typing furiously into his cell phone? Deleuze and Guattari said it best (1977, p. 7) many decades ago: "A huge, pudgy, bloated boy working one of his little desiring-machines, after having hooked it up to a vast technical social machine-which ... is what even the very young child does."

Funding: This research received no external funding.

Conflicts of Interest: The author declares no conflict of interest.

\section{References}

Ahmed, Sara. 2014. The Cultural Politics of Emotion, 2nd ed. New York: Routledge.

Anderson, Ben. 2014. Encountering Affect: Capacities, Apparatuses, Conditions. Farnham: Ashgate.

Anderson, Ben. 2017. "We Will Win Again. We Will Win a Lot": The Affective Styles of Donald Trump. Society and Space. February 28. Available online: https://www.societyandspace.org/articles/we-will-win-again-we-willwin-a-lot-the-affective-styles-of-donald-trump (accessed on 4 May 2020).

Anderson, Ben, and Paul Harrison, eds. 2010. Taking-Place: Non-Representational Theories and Geography. Farnham: Ashgate. Anon. 2019. A Warning. New York: Hachette.

Aune, David E. 1998. Revelation 6-16. Word Biblical Commentary, 52B. Nashville: Thomas Nelson.

Beal, Timothy. 2018. The Book of Revelation: A Biography. Lives of Great Religious Books. Princeton: Princeton University Press.

Beale, G. K. 1999. The Book of Revelation: A Commentary on the Greek Text. The New International Greek New Testament Commentary. Grand Rapids: Eerdmans.

Berlant, Lauren. 2011. Cruel Optimism. Durham: Duke University Press.

Berlant, Lauren. 2016. Trump, or Political Emotions. The New Inquiry. August 5. Available online: https: //thenewinquiry.com/trump-or-political-emotions/ (accessed on 4 May 2020).

Berlant, Lauren. 2017a. Affective Assemblages: Entanglements and Ruptures-An Interview with Lauren Berlant. Atlantis 38: 12-17.

Berlant, Lauren. 2017b. Big Man. Social Text. January 19. Available online: https://socialtextjournal.org/big-man/ (accessed on 4 May 2020).

61 Fox \& Friends interview with President Trump, May 8, 2020, https://factba.se/transcript/donald-trump-interview-fox-andfriends-may-8-2020. For the "blue state/red state" breakdown on COVID-19 casualties, see "COVID-19 Is Hitting Democratic States Harder Than Republican Ones," The Economist, May 22, 2020, https://www.economist.com/graphic-detail/2020/05/22/ covid-19-is-hitting-democratic-states-harder-than-republican-ones.

62 Daniel Smith, "Briefing or Rally? Trump Shifts to Campaign Mode as He Rails against the Media," The Guardian, April 18, 2020, https://www.theguardian.com/us-news/2020/apr/18/donald-trump-press-briefing-rally-campaign-media. 
Black, Fiona C., and Jennifer L. Koosed, eds. 2019. Reading with Feeling: Affect Theory and the Bible. Semeia Studies, 95. Atlanta: SBL Press.

Blount, Brian K. 2005. Can I Get a Witness? Reading Revelation through African American Culture. Louisville: Westminster John Knox Press.

Blount, Brian K. 2007. Revelation. In True to Our Native Land: An African American New Testament Commentary. Edited by Brian K. Blount, Cain Hope Felder, Clarice J. Martin and Emerson B. Powery. Minneapolis: Fortress Press, pp. 523-57.

Blount, Brian K. 2009. Revelation: A Commentary. The New Testament Library. Louisville: Westminster John Knox Press.

Boyd, Candice P., and Christian Edwardes, eds. 2019. Non-Representational Theory and the Creative Arts. New York: Palgrave Macmillan.

Bray, Karen. 2018. Ungrounded Innocence: Confronting Christian Culpability in White Nationalism. In Doing Theology in the Age of Trump: A Critical Report on Christian Nationalism. Edited by Jeffrey W. Robbins and Clayton Crockett. Eugene: Cascade Books, pp. 45-52.

Bray, Karen, and Stephen D. Moore. 2020. Introduction: Mappings and Crossings. In Religion, Emotion, Sensation: Affect Theories and Theologies. Edited by Karen Bray and Stephen D. Moore. Transdisciplinary Theological Colloquia. New York: Fordham University Press, pp. 1-17.

Brinkema, Eugenie. 2014. The Forms of the Affects. Durham: Duke University Press.

Clough, Patricia Ticineto, and Jean Halley, eds. 2007. The Affective Turn: Theorizing the Social. Durham: Duke University Press.

Connolly, William E. 2017. Aspirational Fascism: The Struggle for Multifaceted Democracy Under Trumpism. Forerunners: Ideas First. Minneapolis: University of Minnesota Press.

Dane, Jonathan. 2018. Rise of the Little Horn. Scotts Valley: CreateSpace.

Deleuze, Gilles. 1994. Difference and Repetition. Translated by Paul Patton. New York: Columbia University Press.

Deleuze, Gilles. 1997. Nietzsche and Saint Paul, Lawrence and John of Patmos. In Essays Critical and Clinical. Translated by Daniel W. Smith, and Michael A. Greco. Minneapolis: University of Minnesota Press, pp. 36-52. First published 1978.

Deleuze, Gilles. 2003. Francis Bacon: The Logic of Sensation. Translated by Daniel W. Smith. Minneapolis: University of Minnesota Press.

Deleuze, Gilles, and Félix Guattari. 1977. Anti-Oedipus: Capitalism and Schizophrenia. Translated by Robert Hurley, Mark Seem, and Helen R. Lane. New York: Penguin Books.

Deleuze, Gilles, and Félix Guattari. 1986. Kafka: Toward a Minor Literature. Translated by Dana Polan. Theory and History of Literature, 30. Minneapolis: University of Minnesota Press.

Deleuze, Gilles, and Félix Guattari. 1987. A Thousand Plateaus: Capitalism and Schizophrenia. Translated by Brian Massumi. Minneapolis: University of Minnesota Press. First published 1980.

Deleuze, Gilles, and Félix Guattari. 1994. What Is Philosophy? Translated by Hugh Tomlinson, and Graham Burchell. New York: Columbia University Press.

Emanuel, Sarah. 2020. Humor, Resistance, and Jewish Cultural Persistence in the Book of Revelation: Roasting Rome. Cambridge: Cambridge University Press.

Evans, Tom. 2017. Is Trump REALLY the Antichrist? The Donald's Terrifying 666 Pattern Revealed. Daily Star. January 19. Available online: https://www.dailystar.co.uk/news/latest-news/563055/DonaldTrump-antichrist-satan-666-pattern-president-elect-Hillary-Clinton-occult-devil (accessed on 5 May 2020).

Frankfurter, David. 2001. Jews or Not? Reconstructing the "Other" in Rev 2:9 and 3:9. Harvard Theological Review 94: 403-25.

Gibbs, Anna. 2008. Panic! Affect Contagion, Mimesis and Suggestion in the Social Field. Cultural Studies Review 14: 130-45. [CrossRef]

Gregg, Melissa, and Gregory J. Seigworth, eds. 2010. The Affect Theory Reader. Durham: Duke University Press. Grossberg, Lawrence. 2018. Under the Cover of Chaos: Trump and the Battle for the American Right. London: Pluto Press. Grusin, Richard, ed. 2015. The Nonhuman Turn. 21st Century Studies. Minneapolis: University of Minnesota Press. Hurst, Alexander. 2015. Donald Trump and the Politics of Disgust. The New Republic. December 31. Available online: https://newrepublic.com/article/126837/donald-trump-politics-disgust (accessed on 6 May 2020).

Keller, Catherine. 1996. Apocalypse Now and Then: A Feminist Guide to the End of the World. Boston: Beacon Press. 
Keller, Catherine. 2018. Foxangelicals, Political Theology, and Friends. In Doing Theology in the Age of Trump: A Critical Report on Christian Nationalism. Edited by Jeffrey W. Robbins and Clayton Crockett. Eugene: Cascade Books, pp. 89-100.

Kiel, Micah D. 2017. Apocalyptic Ecology: The Book of Revelation, the Earth, and the Future. Collegeville: Liturgical Press.

Koester, Craig R. 2014. Revelation: A New Translation with Introduction and Commentary. The Anchor Yale Bible. New Haven: Yale University Press.

Koosed, Jennifer L., and Stephen D. Moore, eds. 2014. Affect Theory and the Bible. Biblical Interpretation 22, no. 4 (Thematic Issue). Leiden: Brill.

Kotrosits, Maia. 2015. Rethinking Early Christian Identity: Affect, Violence, and Belonging. Minneapolis: Fortress Press.

Kotrosits, Maia. 2016. How Things Feel: Biblical Studies, Affect Theory, and the (Im)personal. Brill Research Perspectives in Biblical Studies. Leiden: Brill.

LaHaye, Tim, and Jerry B. Jenkins. 1995. Left Behind: A Novel of the Earth's Last Days. Wheaton: Tyndale House.

Levine, Amy-Jill, and Maria Mayo Robbins, eds. 2009. A Feminist Companion to the Apocalypse of John. Feminist Companions to the New Testament and Early Christian Writings, 13. New York: T\&T Clark International.

Li, Fang. 2016. Structure, Function, and Evolution of Coronavirus Proteins. Annual Review of Virology 3: 237-61. [CrossRef] [PubMed]

Marshall, John W. 2001. Parables of War: Reading John's Jewish Apocalypse. Studies in Christianity and Judaism, 10. Waterloo: Wilfred Laurier University Press.

Massumi, Brian. 2002. Parables for the Virtual: Movement, Affect, Sensation. Post-Contemporary Interventions. Durham: Duke University Press.

Massumi, Brian. 2015. Politics of Affect. Cambridge: Polity Press.

Massumi, Brian. 2017. Affect, Power, Violence-The Political Is Not Personal: Brad Evans Interviews Brian Massumi. Los Angeles Review of Books. November 13. Available online: https://lareviewofbooks.org/article/ histories-of-violence-affect-power-violence-the-political-is-not-personal/ (accessed on 4 May 2020).

Massumi, Brian. 2018. 99 Theses on the Revaluation of Value: A Postcapitalist Manifesto. Minneapolis: University of Minnesota Press.

Menéndez-Antuña, Luis. 2018. Thinking Sex with the Great Whore: Deviant Sexualities and Empire in the Book of Revelation. New York: Routledge.

Moelhauser, Lawrence. 2016. The Fourth Beast: Is Donald Trump the Antichrist? Scotts Valley: CreateSpace.

Moore, Stephen D. 2014. Untold Tales from the Book of Revelation: Sex and Gender, Empire and Ecology. Resources for Biblical Study, 79. Atlanta: SBL Press.

Moore, Stephen D. 2017. Gospel Jesuses and Other Nonhumans: Biblical Criticism Post-Poststructuralism. Semeia Studies, 89. Atlanta: SBL Press.

Morgan, Carleigh. 2017. “Trump: Image without Body.”. Furtherfield. May 18. Available online: https://www. furtherfield.org/trump-image-without-body/ (accessed on 4 May 2020).

Ngai, Sianne. 2005. Ugly Feelings. Cambridge: Harvard University Press.

O'Brien, Gerald V. 2018. Contagion and the National Body: The Organism Metaphor in American Thought. New York: Routledge.

Ogbar, Jeffrey O. G. 2004. Black Power: Radical Politics and African American Identity. Baltimore: Johns Hopkins University Press.

Ott, Brian L. 2017. The Age of Twitter: Donald J. Trump and the Politics of Debasement. Critical Studies in Media Communication 34: 59-68. [CrossRef]

Ott, Brian L., and Greg Dickinson. 2019. The Twitter Presidency: Donald J. Trump and the Politics of White Rage. New York: Routledge.

Pippin, Tina. 1992. Death and Desire: The Rhetoric of Gender in the Apocalypse of John. Literary Currents in Biblical Interpretation. Louisville: Westminster John Knox Press.

Pitney, John J., Jr. 2020. Un-American: The Fake Patriotism of Donald J. Trump. Lanham: Rowman \& Littlefield.

Rainbow, Jesse. 2007. Male mastoi in Revelation 1.13. Journal for the Study of the New Testament 30: $249-53$. [CrossRef]

Rhoads, David, ed. 2005. From Every People and Nation: The Book of Revelation in Intercultural Perspective. Minneapolis: Fortress Press.

Richardson, Michael. 2017. The Disgust of Donald Trump. Continuum 31: 747-56. [CrossRef] 
Roffe, Jon, and Hannah Stark, eds. 2015. Deleuze and the Non/Human. New York: Palgrave Macmillan.

Rossing, Barbara R. 2002. Alas for Earth! Lament and Resistance in Revelation 12. In The Earth Story in the New Testament. Edited by Norman C. Habel and Vicki Balabanski. Cleveland: The Pilgrim Press, pp. 180-92.

Rossing, Barbara R. 2005. For the Healing of the World: Reading Revelation Ecologically. In From Every People and Nation: The Book of Revelation in Intercultural Perspective. Edited by David Rhoads. Minneapolis: Fortress Press, pp. 165-82.

Rossing, Barbara R. 2007. The Rapture Exposed: The Message of Hope in the Book of Revelation, 2nd ed. New York: Basic Books.

Sánchez, David A. 2008. From Patmos to the Barrio: The Subversion of Imperial Myths from the Book of Revelation to the Present. Minneapolis: Fortress Press.

Schaefer, Donovan O. 2015. Religious Affects: Animality, Evolution, and Power. Durham: Duke University Press.

Schaefer, Donovan O. 2019. Whiteness and Civilization: Shame, Race, and the Rhetoric of Donald Trump. Communication and Critical/Cultural Studies 17: 1-18. [CrossRef]

Schússler Fiorenza, Elisabeth. 2007. The Power of the Word: Scripture and the Rhetoric of Empire. Minneapolis: Fortress Press.

Smith, Shanell T. 2014. The Woman Babylon and the Marks of Empire: Reading Revelation with a Postcolonial Womanist Hermeneutics of Ambiveilence. Emerging Scholars Series; Minneapolis: Fortress Press.

Thomas, Eric A. 2018. The Futures Outside: Apocalyptic Epilogue Unveiled as Africana Queer Prologue. In Sexual Disorientations: Queer Temporalities, Affects, Theologies. Edited by Kent L. Brintnall, Joseph A. Marchal and Stephen D. Moore. Transdisciplinary Theological Colloquia. New York: Fordham University Press, pp. 90-112.

Thrift, Nigel. 2008. Non-Representational Theory: Space, Politics, Affect. International Library of Sociology. New York: Routledge.

Trump, Donald J. 2015. Crippled America: How to Make America Great Again. New York: Simon \& Schuster. Trump, Donald J., and Tony Schwartz. 1987. Trump: The Art of the Deal. New York: Ballantine Books.

Vannini, Phillip. 2015. Non-Representational Research Methodologies: An Introduction. In Non-Representational Methodologies: Re-Envisioning Research. Edited by Phillip Vannini. Routledge Advances in Research Methods. New York: Routledge, pp. 1-18.

Varos, D. Xander. 2017. Is Trump the Antichrist? Denver: Bygone Era Books.

(C) 2020 by the author. Licensee MDPI, Basel, Switzerland. This article is an open access article distributed under the terms and conditions of the Creative Commons Attribution (CC BY) license (http://creativecommons.org/licenses/by/4.0/). 